1 Supporting information for

2

\title{
Synthesis and Herbicidal Activity of Triketone-Aminopyridines as Potent HPPD Inhibitors
}

Jia-Xu Nan," Jing-Fang Yang," Lin-Hong Yan, Yao-Chao Yan, Shao-Meng Zhou, Xue-Fang Wei, Qiong Chen, Wen-Chao Yang, Ren-Yu Qu,* and Guang-Fu Yang*

Key Laboratory of Pesticide \& Chemical Biology of Ministry of Education, International Joint

Research Center for Intelligent Biosensor Technology and Health, College of Chemistry, Central China Normal University, Wuhan 430079, P. R. China

(1)

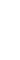

\section{AUTHOR INFORMATION}

\# Both these authors contributed equally to this work.

*Corresponding Authors:

Tel: +86-27-67867800, Fax: +86-27-67867141, E-mail: renyu@mail.ccnu.edu.cn (Ren-Yu

Qu); gfyang@mail.ccnu.edu.cn (Guang-Fu Yang).

ORCID:

Ren-Yu Qu: 0000-0002-6669-862X

Guang-Fu Yang: 0000-0003-4384-2593 
$X$-ray Diffraction. 
41

\section{$X$-ray Diffraction.}

area detector diffractometer with graphite monochromatic Mo Ka radiation, $\theta \max =25.49$, 16744 measured reflections, and 4817 independent reflections. The data sets were adjusted with the SAINT plus Programme. The crystal structure was analyzed through a direct method with SHELXS97 and refined with SHELXL970. Hydrogen atoms were placed at their ideal positions according to the fixed value of their isotropic displacement parameter. The crystallographic data of compound $\mathbf{1 6}$ was shown in Table S1. 


\begin{tabular}{|c|c|c|}
\hline Name & \multicolumn{2}{|l|}{ Value } \\
\hline Empirical formula & \multicolumn{2}{|l|}{$\mathrm{C}_{19} \mathrm{H}_{14} \mathrm{Cl}_{4} \mathrm{~N}_{2} \mathrm{O}_{3}$} \\
\hline Identification code & \multicolumn{2}{|l|}{ mo_191017a_0m } \\
\hline Formula weight & \multicolumn{2}{|l|}{460.12} \\
\hline Temperature & \multicolumn{2}{|l|}{$296(2) \mathrm{K}$} \\
\hline Wavelength & \multicolumn{2}{|l|}{$0.71073 \AA$} \\
\hline Crystal system & \multicolumn{2}{|l|}{ Triclinic } \\
\hline Space group & \multicolumn{2}{|l|}{$\mathrm{P}-1$} \\
\hline \multirow[t]{3}{*}{ Unit cell dimensions } & $\mathrm{a}=8.4410(12) \AA$ & $\alpha=100.731(2)^{\circ}$ \\
\hline & $b=10.0153(14) \AA$ & $\beta=91.562(2)^{\circ}$ \\
\hline & $\mathrm{c}=11.8418(17) \AA$ & $\gamma=90.786(2)^{\circ}$ \\
\hline Volume & \multicolumn{2}{|l|}{$983.0(2) \AA^{3}$} \\
\hline $\mathrm{Z}$ & \multicolumn{2}{|l|}{2} \\
\hline Density (calculated) & \multicolumn{2}{|l|}{$1.554 \mathrm{Mg} / \mathrm{m}^{3}$} \\
\hline Absorption coefficient & \multicolumn{2}{|l|}{$0.626 \mathrm{~mm}^{-1}$} \\
\hline $\mathrm{F}(000)$ & \multicolumn{2}{|l|}{468} \\
\hline Crystal size & \multicolumn{2}{|l|}{$0.12 \times 0.12 \times 0.01 \mathrm{~mm}^{3}$} \\
\hline Theta range for data collection & \multicolumn{2}{|l|}{1.751 to $31.824^{\circ}$} \\
\hline Index ranges & \multicolumn{2}{|c|}{$-12<=\mathrm{h}<=9,-14<=\mathrm{k}<=14,-16<=1<=16$} \\
\hline Reflections collected & \multicolumn{2}{|l|}{10472} \\
\hline Completeness to theta $=25.242^{\circ}$ & \multicolumn{2}{|l|}{$99.2 \%$} \\
\hline Absorption correction & \multicolumn{2}{|c|}{ Semi-empirical from equivalents } \\
\hline Refinement method & \multicolumn{2}{|c|}{ Full-matrix least-squares on $\mathrm{F}^{2}$} \\
\hline Data / restraints / parameters & \multicolumn{2}{|l|}{$6015 / 30 / 268$} \\
\hline Goodness-of-fit on $\mathrm{F}^{2}$ & \multicolumn{2}{|l|}{1.090} \\
\hline Final $\mathrm{R}$ indices $[\mathrm{I}>2 \operatorname{sigma}(\mathrm{I})]$ & \multicolumn{2}{|c|}{$\mathrm{R} 1=0.0571, \mathrm{wR} 2=0.1432$} \\
\hline $\mathrm{R}$ indices (all data) & \multicolumn{2}{|c|}{$\mathrm{R} 1=0.0684, \mathrm{wR} 2=0.1581$} \\
\hline Extinction coefficient & \multicolumn{2}{|l|}{$0.104(5)$} \\
\hline Largest diff. peak and hole & \multicolumn{2}{|c|}{0.347 and -0.577 e. $\AA^{3}$} \\
\hline
\end{tabular}




\section{Binding Free Energies Calculations.}

Three-step energy-minimization was performed to the AtHPPD-inhibitor complex before binding free energy calculation. Firstly, the ions and hydrogens were minimized, and others were fixed. Secondly, the backbone atoms of AtHPPD were fixed, and other atoms were allowed to move. Thirdly, all atoms were free to move. In the three steps, we all used 2000 steps steepest descent method and conjugated gradient method for the next 200 steps.

The binding free energy $\left(\Delta G_{\text {bind }}\right.$ ) between receptor and ligand is calculated by the MM-PBSA method. It is obtained by calculating the difference of free energies between the ligand-receptor complex $\left(G_{\text {cpx }}\right)$ and the unbound receptor $\left(G_{\text {rec }}\right)$ and ligand $\left(G_{\text {lig }}\right)$ as the equation (1). Moreover, The $\Delta G_{\text {bind }}$ includes three parts, the molecular mechanical (MM) gas-phase binding energy $\left(\Delta E_{\mathrm{MM}}\right)$, solvation free energy $\left(\Delta G_{\mathrm{sol}}\right)$, and entropic contribution $(-T \Delta S)$ as the equation (2).

$$
\begin{aligned}
& \Delta G_{\text {bind }}=G_{\mathrm{cpx}}-\left(G_{\mathrm{rec}}+G_{\text {lig }}\right) \\
& \Delta G_{\text {bind }}=\Delta E_{\mathrm{MM}}+\Delta G_{\mathrm{sol}}-T \Delta S
\end{aligned}
$$

Amongst all, the $\Delta \mathrm{E}_{\mathrm{MM}}$ consists of the electrostatic energies $\left(\Delta E_{\text {ele }}\right)$ and Van der Waals interaction $\left(\Delta E_{\mathrm{vdW}}\right)$ :

$$
\Delta E_{\mathrm{MM}}=\Delta E_{\mathrm{ele}}+\Delta E_{\mathrm{VdW}}
$$

The $\Delta G_{\mathrm{sol}}$ is made up of electrostatic contribution $\left(\Delta G_{\mathrm{PB}}\right)$ and nonelectrostatic contribution $\left(\Delta G_{\mathrm{np}}\right)$ to the solvation-free energy. $\Delta G_{\mathrm{PB}}$ is calculated by the Poisson-Boltzman (PB) method using the MM-PBSA module in AMBER16 program. $\Delta G_{\mathrm{np}}$ is determined by the solvent accessible surface area.

$$
\Delta G_{\mathrm{sol}}=\Delta G_{\mathrm{PB}}+\Delta G_{\mathrm{np}}
$$

For the entropic contribution, an empirical method was used, it consists of two subitems, the solvation entropy change $\left(\Delta S_{\text {sol }}\right)$ and conformational entropy change $\left(\Delta S_{\text {conf }}\right)$ :

$$
\Delta S=\Delta S_{\text {sol }}+\Delta S_{\text {conf }}
$$


The $\Delta S_{\text {sol }}$ is obtained by the tendency of water molecules to minimize their contacts with hydrophobic groups in protein, $\Delta S_{\text {conf }}$ is related to the change of the number of rotatable bonds during the binding process. The entropic contribution is evaluated, and the conformational entropy change is proportional to the number $\left(\Delta N_{\text {rot }}\right)$ of the lost rotatable bonds during the binding:

in which $w$ is a scaling factor set as $1 \mathrm{Kcal} / \mathrm{mol}$ for the binding energy calculation. Thus, equation (2) can be written as:

$$
\Delta G_{\text {bind }}=\Delta E_{\mathrm{MM}}+\Delta G_{\mathrm{PB}}+\Delta G_{\mathrm{np}}-T \Delta S_{\mathrm{sol}}+w\left(\Delta N_{\mathrm{rot}}\right)
$$
all other parameters in the energy calculation are the standard parameters or the default values of the AMBER16 program. 


\section{The expression and purification of $\boldsymbol{A t H P P D}$}

we selected $A t \mathrm{HPPD}$ as the target enzyme to assess the biological activity of all synthesized compounds. In the first instance, we utilized cDNA of HPPD in the pMD19-T sample to constructed the $A t$ HPPD by polymerase chain reaction (PCR) as the template. And the DNA sequences of the positive clones were certified through DNA sequencing with Shanghai SANGON Company. The next, Recombinant AtHPPD and recombinant HGD from human were overexpressed in E. coli BL21(DE3) cells in accordance with the previous publication. Expression of the AtHPPD was incubated at $37^{\circ} \mathrm{C}$ for $12 \mathrm{~h}$. we put to use $0.5 \mathrm{mM}$ isopropyl- $\beta$-Dthiogalactopyranoside (IPTG) to induce HGD when bacterial growth attained $A_{600}$ of 0.6 , and then incubated the E. coli BL21(DE3) cells for another $40 \mathrm{~h}$ at $15{ }^{\circ} \mathrm{C}$. The precipitant harvesting by centrifugation at $20000 \mathrm{~g}$ for $30 \mathrm{~min}$ was resuspended in $20 \mathrm{mM} \mathrm{N}-2-$ hydroxyethylpiperazine-N'-2-ethanesulfonic acid (HEPES) buffer and $20 \mathrm{mM} \mathrm{NaCl}$ at $\mathrm{pH}$ 7.0. After sonication with a cell disruptor, we obtained a crude cell-free supernatant by centrifugation $(20000 \mathrm{~g}$ for $30 \mathrm{~min})$. The overexpression and molecular weight of recombinant AtHPPD were authenticated through sodium dodecyl sulfate polyacrylamide gel electrophoresis (SDS-PAGE) colored with Coomassie Brilliant Blue-R250 and simple analysis using Simon instrumentation (ProteinSimple, CA). Finally, we selected a nickel-nitrilotriacetic acid (Ni-NTA) column (Qiagen, Canada) to load the crude cell-free supernatant at $\mathrm{pH} 7.0$ with HEPES. Then, HPPD was eluted using $150 \mathrm{mM} \mathrm{NaCl}, 250 \mathrm{mM}$ imidazole, and $20 \mathrm{mM}$ HEPES at $\mathrm{pH}$ 7.0. The HPPD fractions were concentrated, and the buffer was exchanged by ultrafiltration in Ultrafree filter devices (Millipore, MA) for $20 \mathrm{mM}$ HEPES at $\mathrm{pH}$ 7.0. The anion-exchange chromatography was executed for further purification of the Recombinant AtHPPD on Q resin (Amersham-Pharmacia Biotech, Germany) with $20 \mathrm{mM}$ HEPES at pH 7.0. And then, HPPD was eluted in a linear gradient from 0 to $250 \mathrm{mM} \mathrm{NaCl}$. We collected the 
106 fractions containing HPPD and exchanged the buffer with $20 \mathrm{mM}$ HEPES at $\mathrm{pH} 7.0$ through 107 ultrafiltration.

108

109

110 
Figure 1 The ${ }^{1} \mathrm{H}$ NMR (400M $\mathrm{CDCl}_{3}$ ) of compound 10

iุ
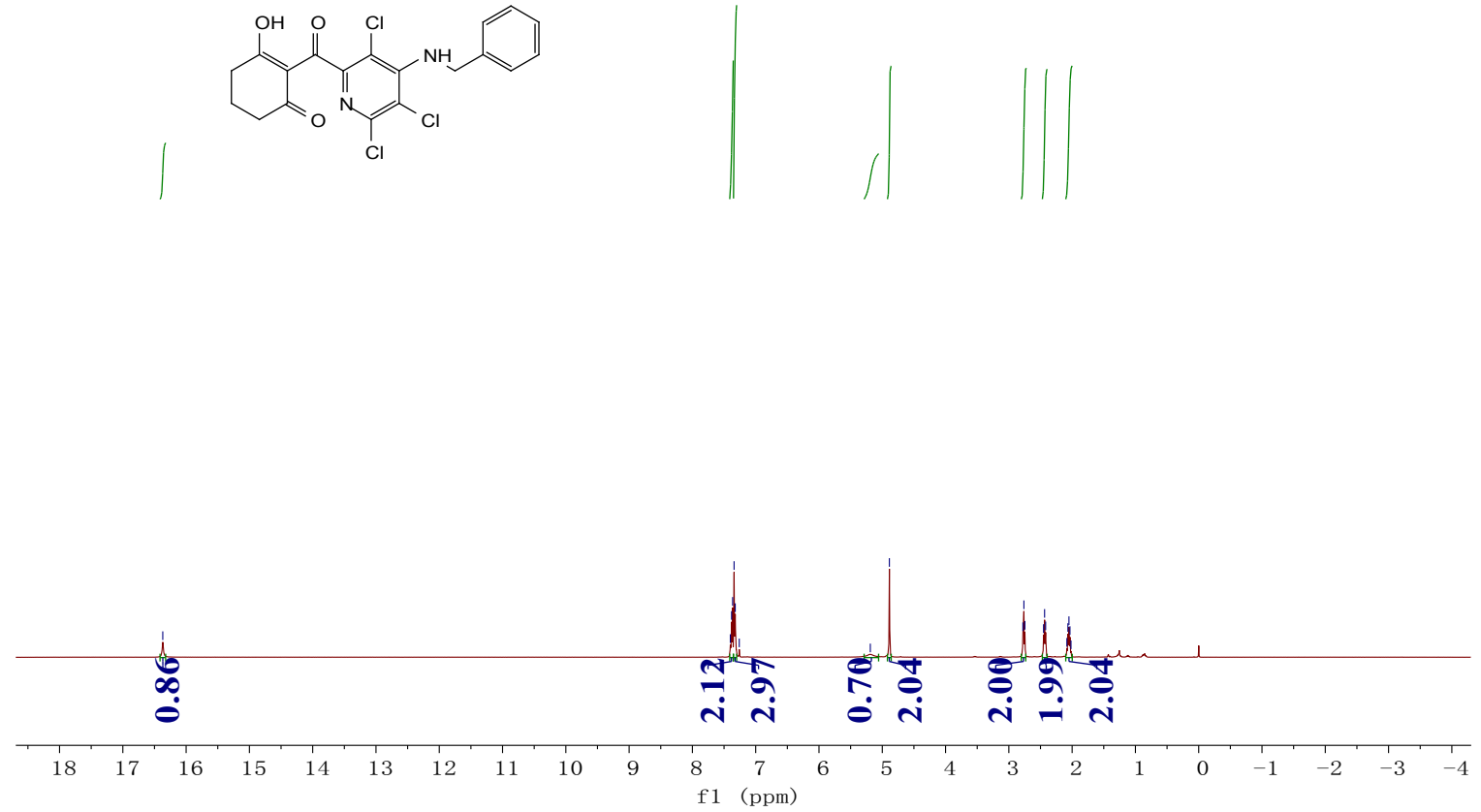

Figure 2 The ${ }^{13} \mathrm{C}$ NMR $\left(100 \mathrm{M} \mathrm{CDCl}_{3}\right)$ of compound 10
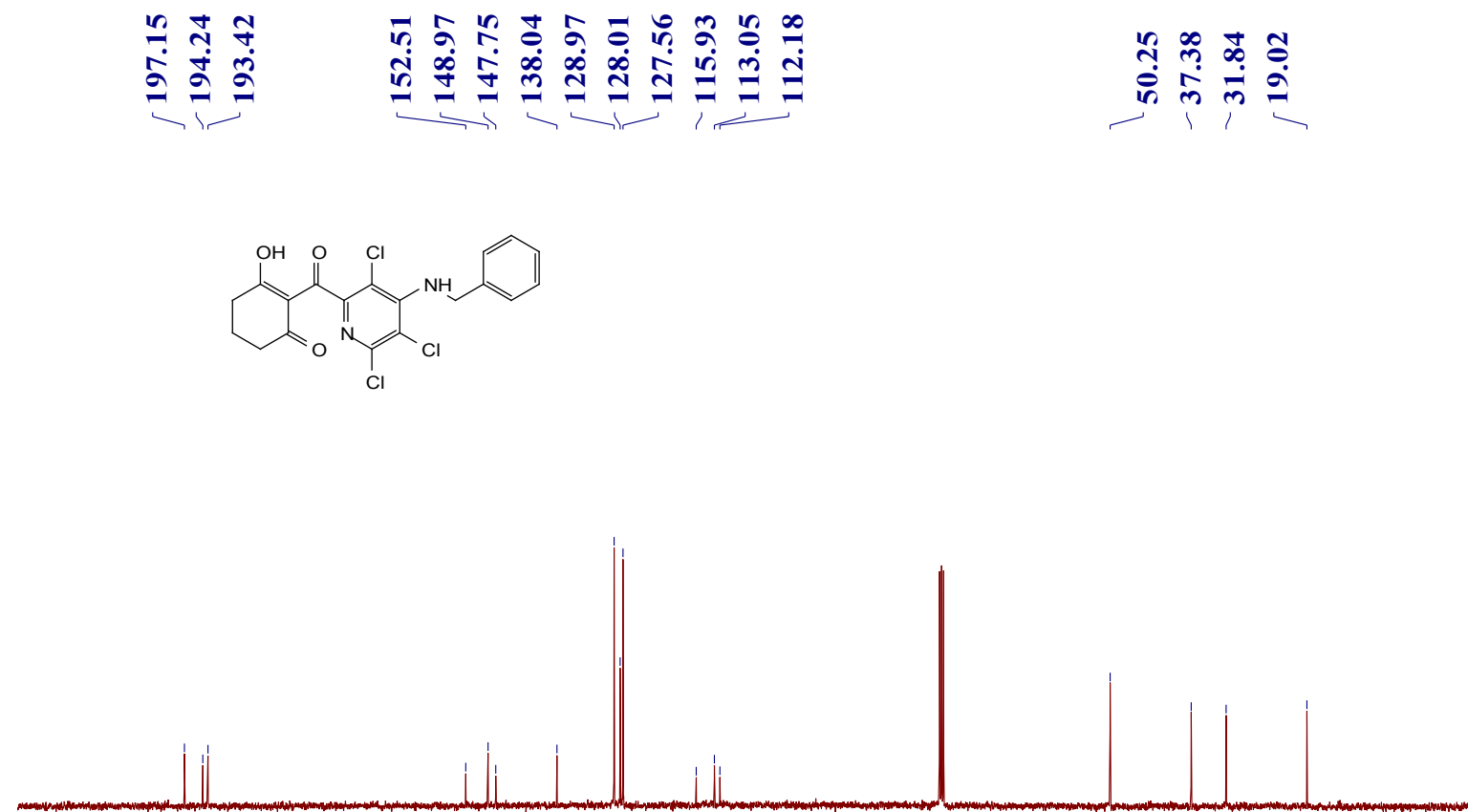
<smiles>O=C1CCCC(O)=C1C(=O)c1nc(Cl)c(Cl)c(NCc2ccccc2F)c1Cl</smiles>

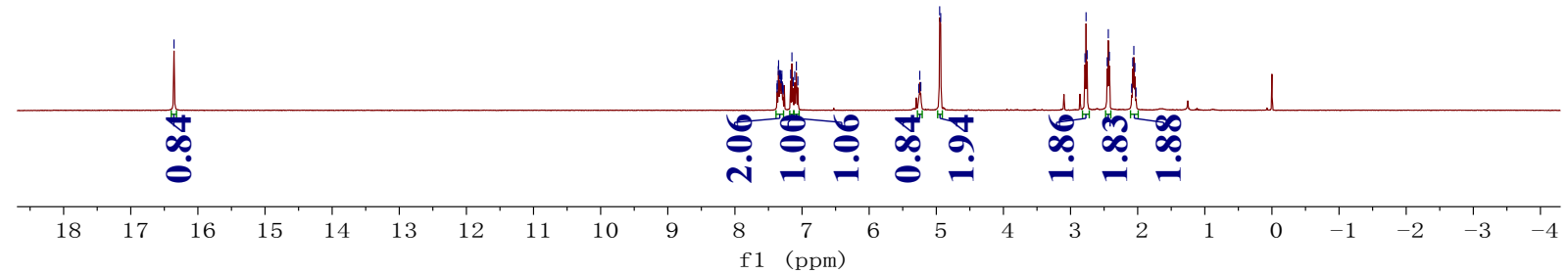

Figure 4 The ${ }^{13} \mathrm{C}$ NMR $\left(100 \mathrm{M} \mathrm{CDCl}_{3}\right)$ of compound 11

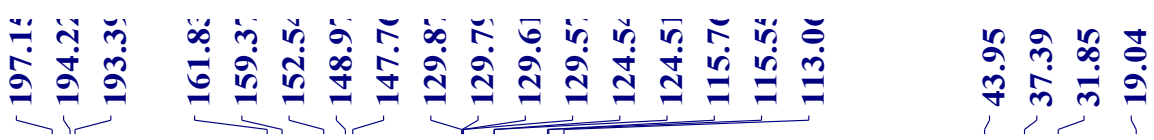<smiles>O=C1CCCC(O)=C1C(=O)c1nc(Cl)c(Cl)c(NCc2ccccc2F)c1Cl</smiles> 
Figure 5 The ${ }^{1} \mathrm{H}$ NMR (400M CDCl 3 ) of compound 12

กัด

ஸे<smiles>O=C1CCCC(O)=C1C(=O)c1nc(Cl)c(Cl)c(NCc2cccc(F)c2)c1Cl</smiles>

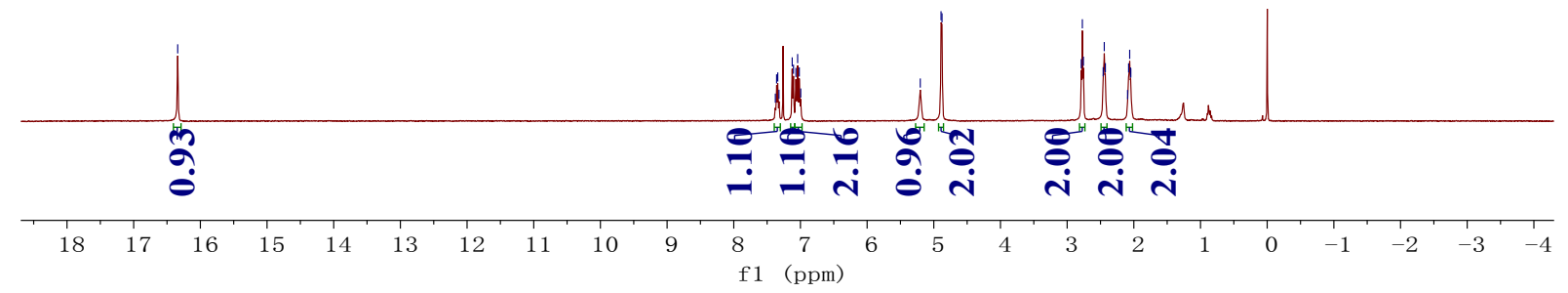

Figure 6 The ${ }^{13} \mathrm{C}$ NMR (100M $\mathrm{CDCl}_{3}$ ) of compound 12

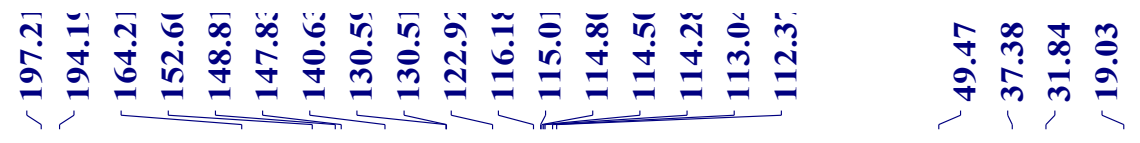<smiles>O=C1CCCC(O)=C1C(=O)c1nc(Cl)c(Cl)c(NCc2cccc(F)c2)c1Cl</smiles> 
Figure 7 The ${ }^{1} \mathrm{H}$ NMR (400M CDCl 3 ) of compound 13

"ֶ̣:<smiles>O=C1CCCC(O)=C1C(=O)c1nc(Cl)c(Cl)c(NCc2ccc(F)cc2)c1Cl</smiles>

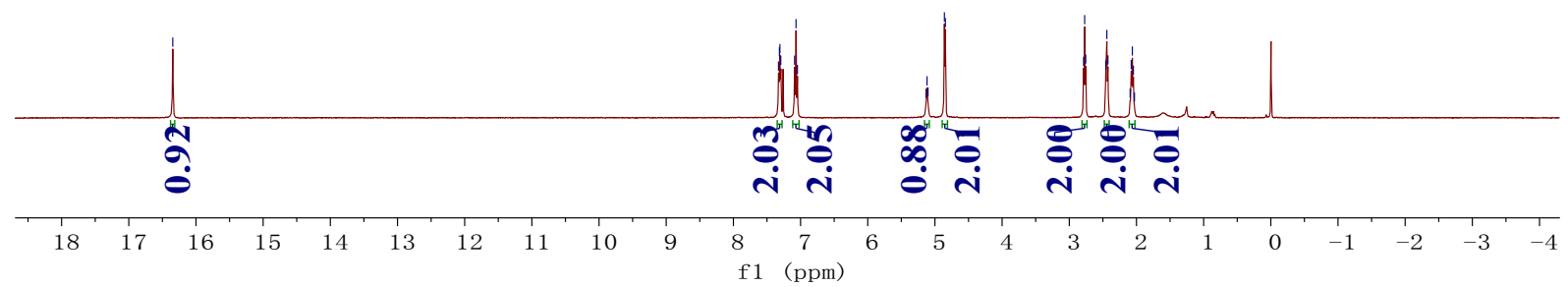

Figure 8 The ${ }^{13} \mathrm{C}$ NMR (100M $\mathrm{CDCl}_{3}$ ) of compound 13

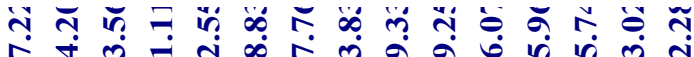

$\hat{\sigma} \dot{a}$ ஸ்

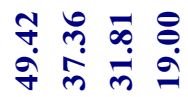<smiles>O=C1CCCC(O)=C1C(=O)c1nc(Cl)c(Cl)c(NCc2ccc(F)cc2)c1Cl</smiles> 
Figure 9 The ${ }^{1} \mathrm{H} \mathrm{NMR}\left(400 \mathrm{M} \mathrm{CDCl}_{3}\right)$ of compound 14

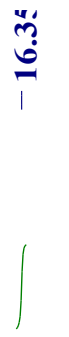

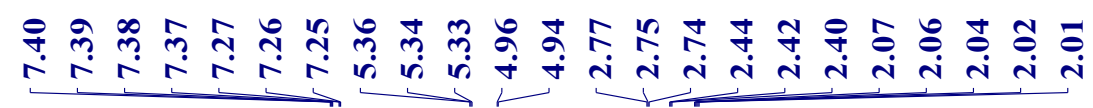<smiles>O=C1CCCC(O)=C1C(=O)c1nc(Cl)c(Cl)c(NCc2ccccc2Cl)c1Cl</smiles>
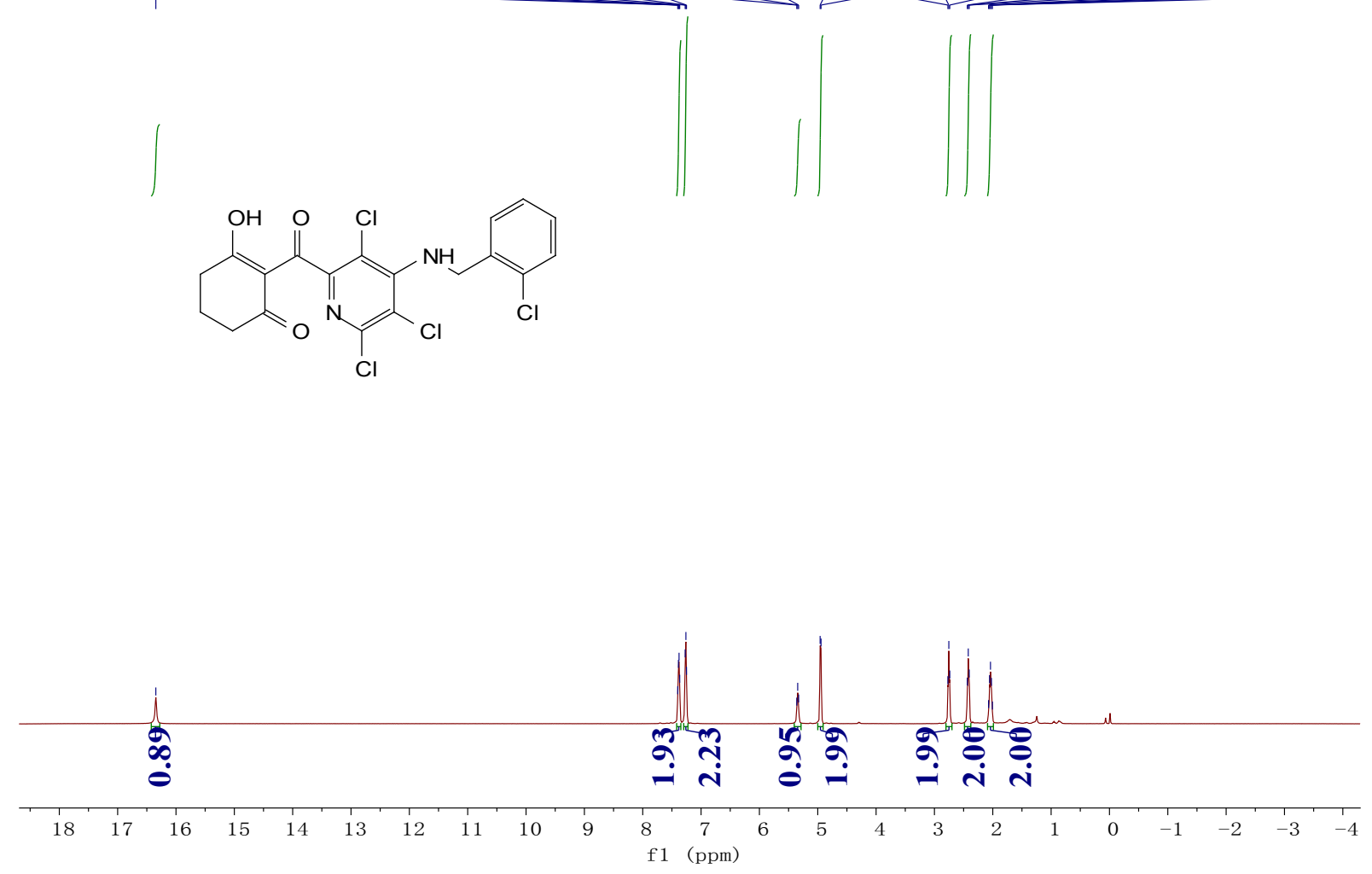

Figure 10 The ${ }^{13} \mathrm{C}$ NMR $\left(100 \mathrm{M} \mathrm{CDCl}_{3}\right)$ of compound 14

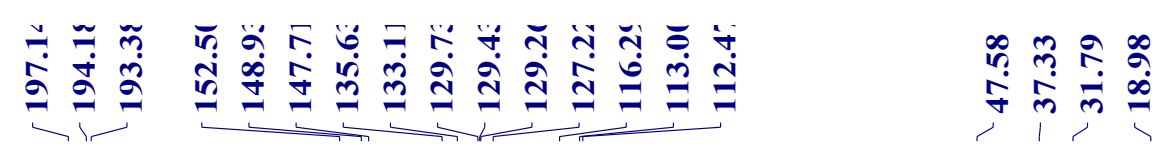<smiles>O=C1CCCC(O)=C1C(=O)c1nc(Cl)c(Cl)c(NCc2ccccc2Cl)c1Cl</smiles>

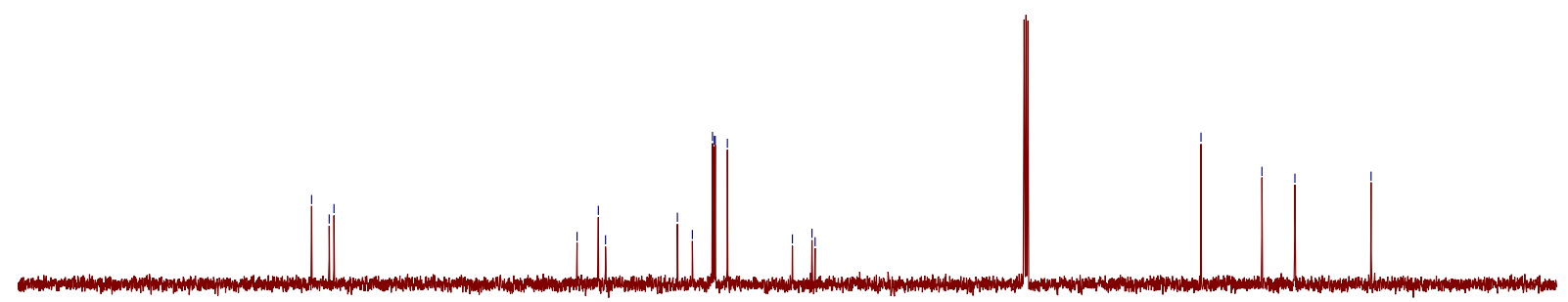


Figure 11 The ${ }^{1} \mathrm{H} \mathrm{NMR}\left(400 \mathrm{M} \mathrm{CDCl}_{3}\right.$ ) of compound 15

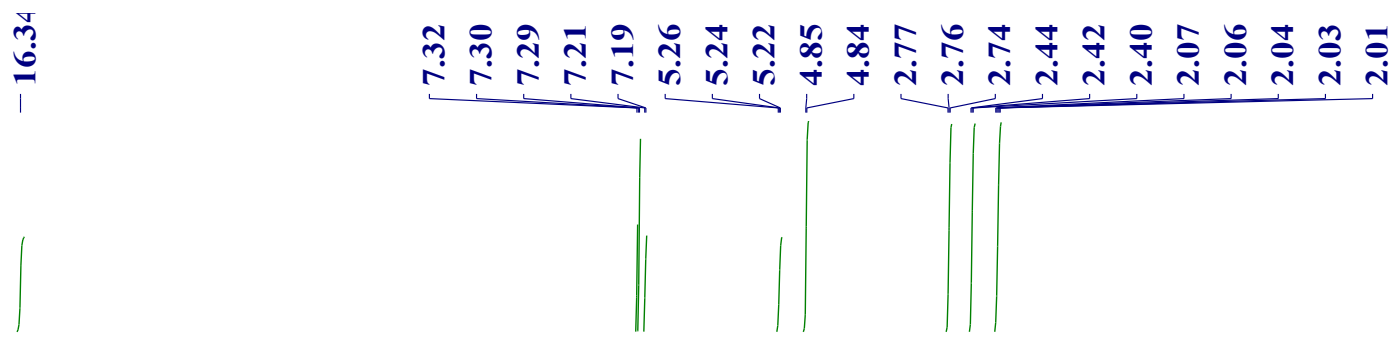<smiles>O=C1CCCC(O)=C1C(=O)c1nc(Cl)c(Cl)c(NCc2cccc(Cl)c2)c1Cl</smiles>

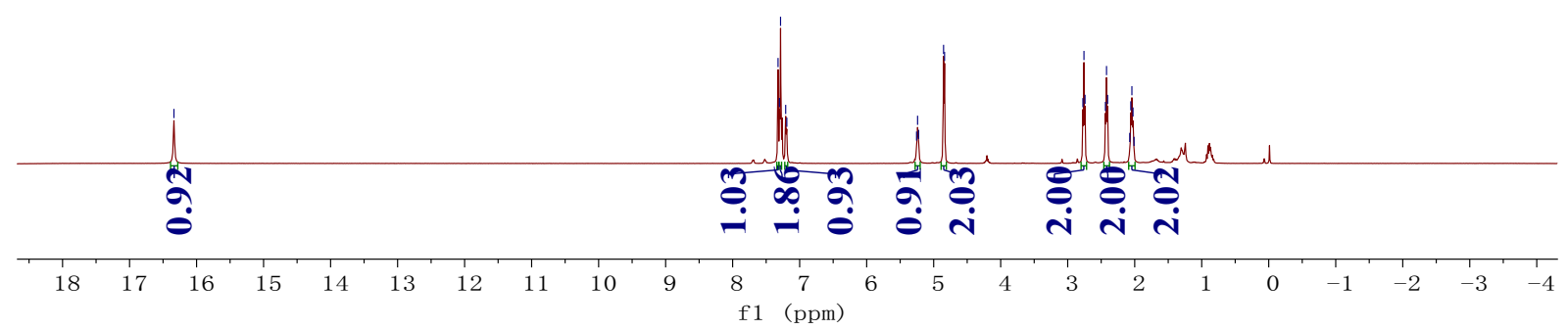

Figure 12 The $\left.{ }^{13} \mathrm{C} \mathrm{NMR} \mathrm{(100M} \mathrm{CDCl}_{3}\right)$ of compound 15

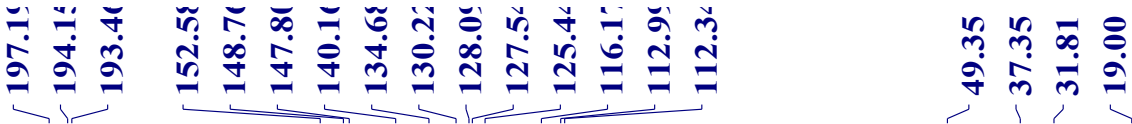<smiles>O=C1CCCC(O)=C1C(=O)c1nc(Cl)c(Cl)c(NCc2cccc(Cl)c2)c1Cl</smiles> 
Figure 13 The ${ }^{1} \mathrm{H}$ NMR (400M $\mathrm{CDCl}_{3}$ ) of compound 16

$$
\begin{aligned}
& \stackrel{\text { ตุ }}{1} \\
& 1
\end{aligned}
$$

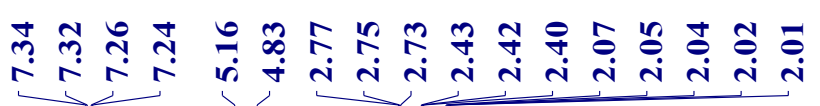
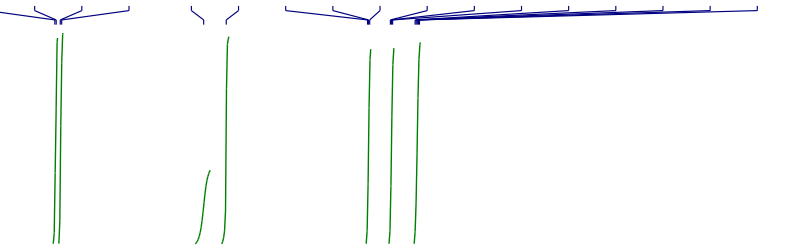<smiles>O=C1CCCC(O)=C1C(=O)c1nc(Cl)c(Cl)c(NCc2ccc(Cl)cc2)c1Cl</smiles>

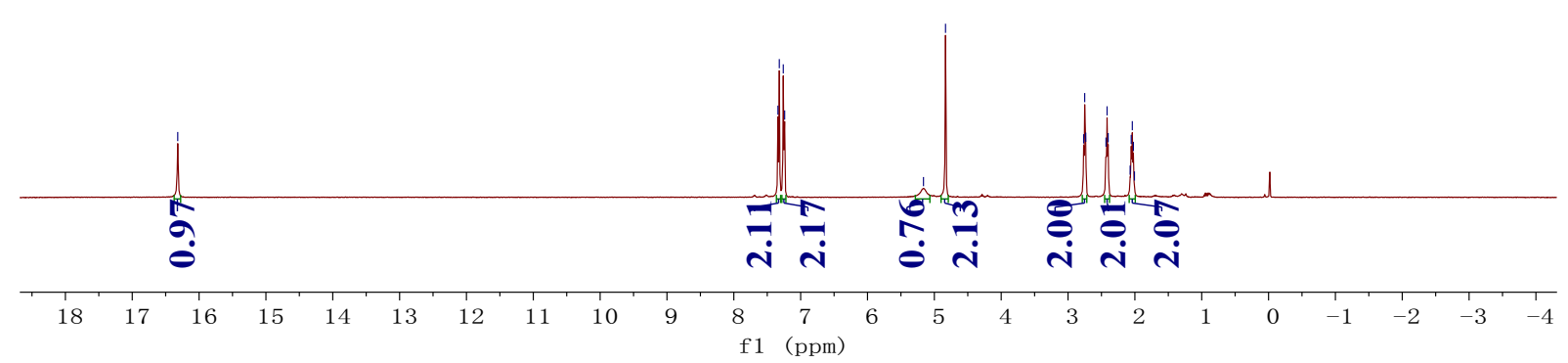

Figure 14 The ${ }^{13} \mathrm{C}$ NMR $\left(100 \mathrm{M} \mathrm{CDCl}_{3}\right)$ of compound 16

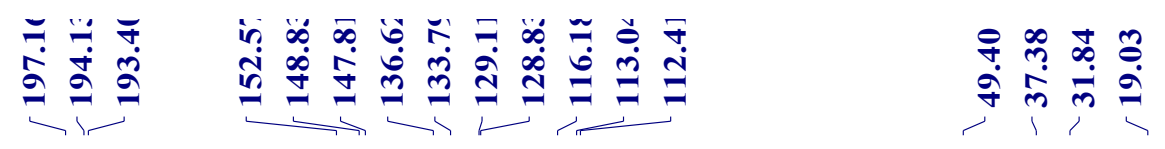<smiles>O=C1CCCC(O)=C1C(=O)c1nc(Cl)c(Cl)c(NCc2ccc(Cl)cc2)c1Cl</smiles> 
Figure 15 The ${ }^{1} \mathrm{H}$ NMR (400M $\mathrm{CDCl}_{3}$ ) of compound 17

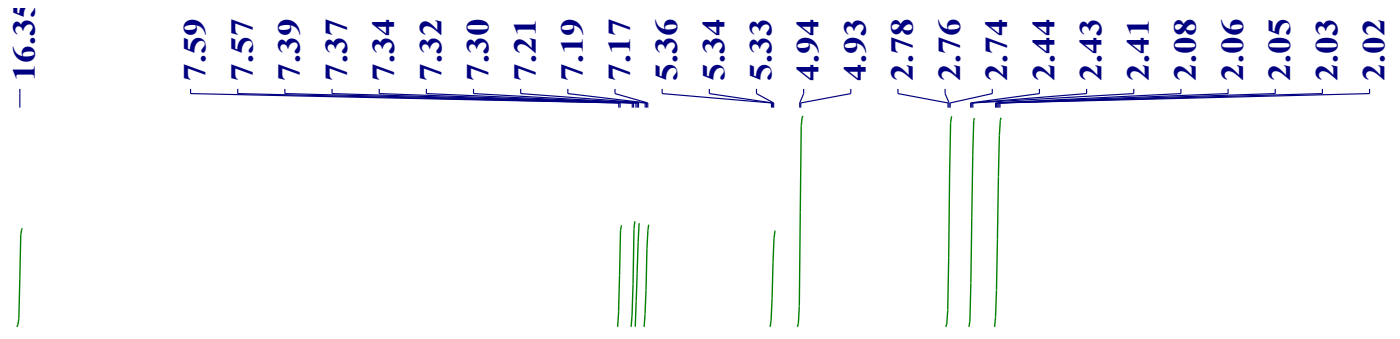<smiles>O=C1CCCC(O)=C1C(=O)c1nc(Cl)c(Cl)c(NCc2ccccc2Br)c1Cl</smiles>

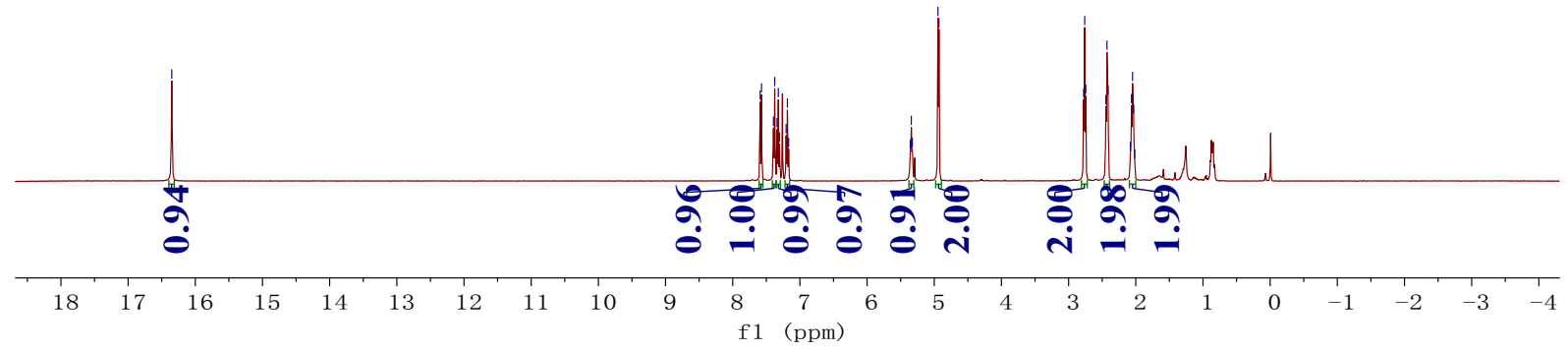

Figure 16 The ${ }^{13} \mathrm{C}$ NMR $\left(100 \mathrm{M} \mathrm{CDCl}_{3}\right)$ of compound 17

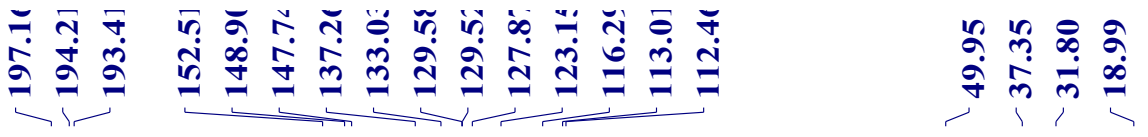<smiles>O=C1CCCC(O)=C1C(=O)c1nc(Cl)c(Cl)c(NCc2ccccc2Br)c1Cl</smiles> 
Figure 17 The ${ }^{1} \mathrm{H}$ NMR (400M $\mathrm{CDCl}_{3}$ ) of compound 18

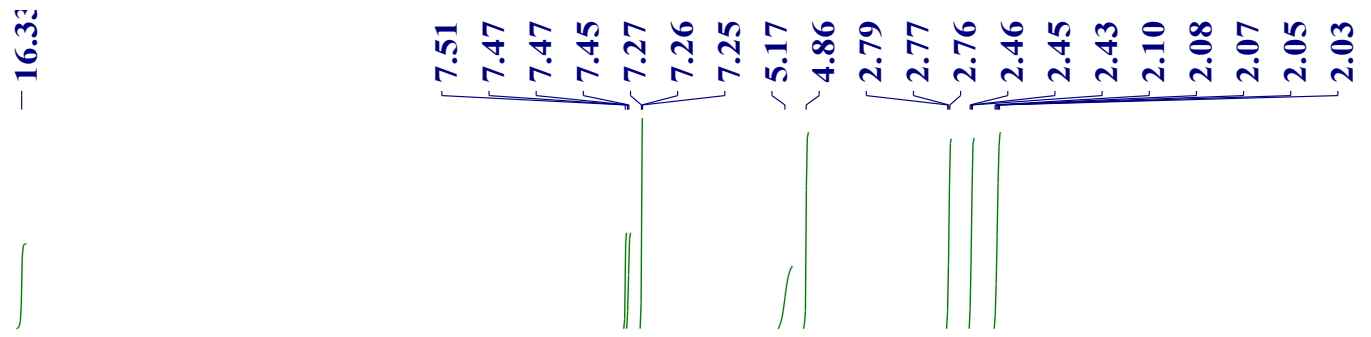<smiles>O=C1CCCC(O)=C1C(=O)c1nc(Cl)c(Cl)c(NCc2cccc(Br)c2)c1Cl</smiles>

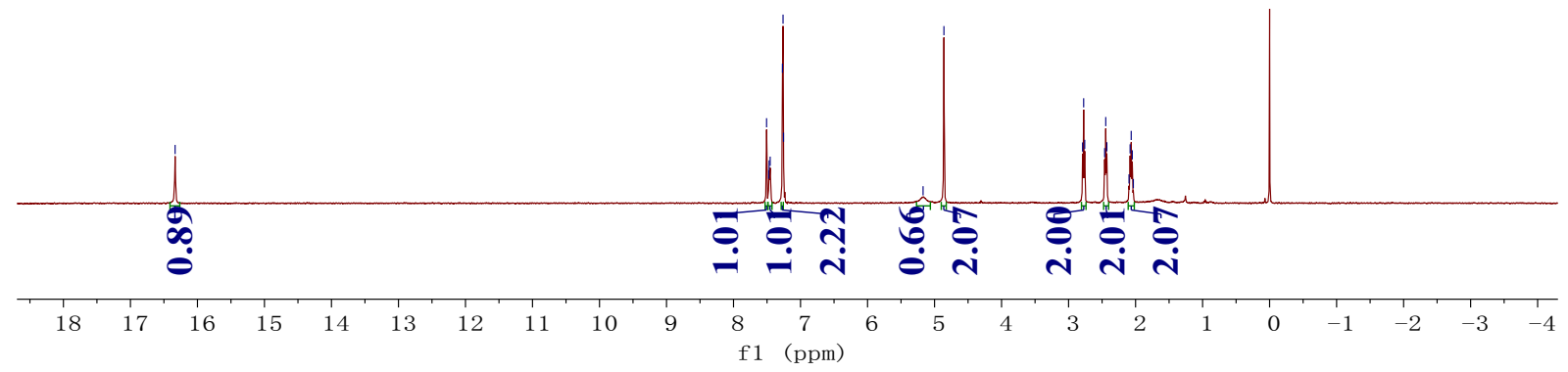

Figure 18 The ${ }^{13} \mathrm{C}$ NMR (100M $\left.\mathrm{CDCl}_{3}\right)$ of compound 18

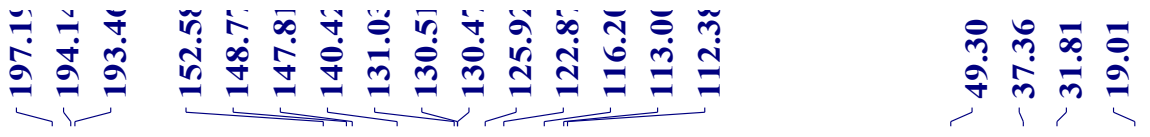<smiles>O=C1CCCC(O)=C1C(=O)c1nc(Cl)c(Cl)c(NCc2cccc(Br)c2)c1Cl</smiles> 
Figure 19 The ${ }^{1} \mathrm{H}$ NMR (400M $\mathrm{CDCl}_{3}$ ) of compound 19

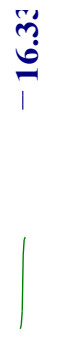

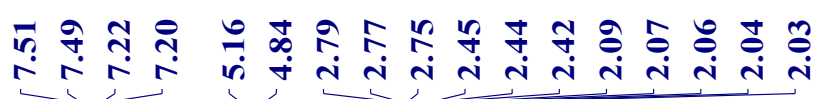<smiles>O=C1CCCC(O)=C1C(=O)c1nc(Cl)c(Cl)c(NCc2ccc(Br)cc2)c1Cl</smiles>

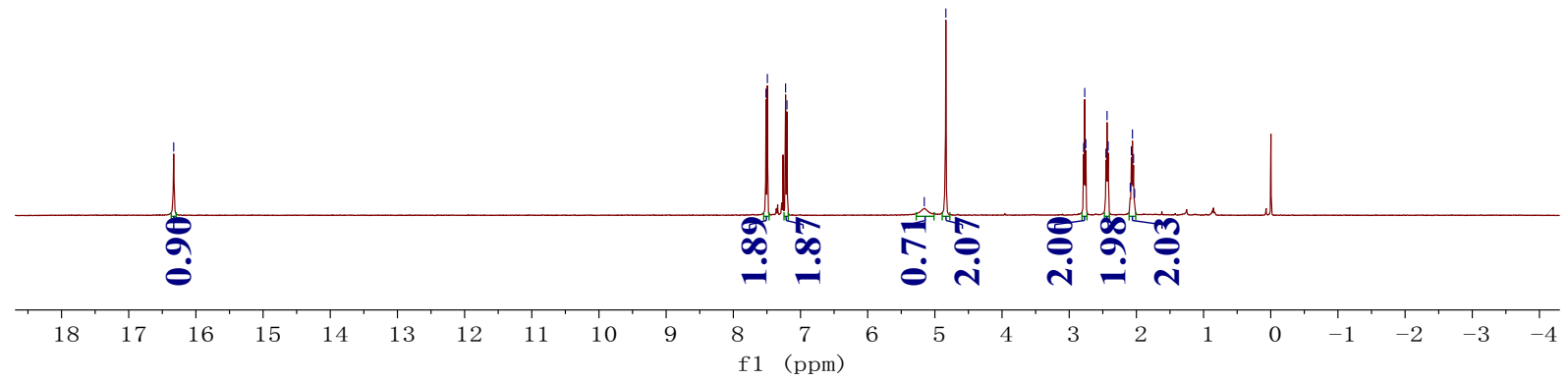

Figure 20 The ${ }^{13} \mathrm{C}$ NMR $\left(100 \mathrm{M} \mathrm{CDCl}_{3}\right)$ of compound 19

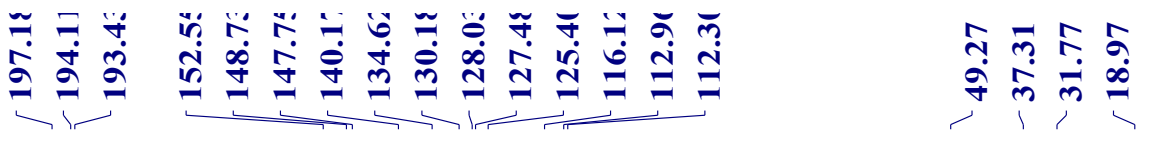<smiles>O=C1CCCC(O)=C1C(=O)c1nc(Cl)c(Cl)c(NCc2ccc(Br)cc2)c1Cl</smiles> 
Figure 21 The ${ }^{1} \mathrm{H}$ NMR (400M $\mathrm{CDCl}_{3}$ ) of compound 20

ֻู่<smiles>C=C</smiles>

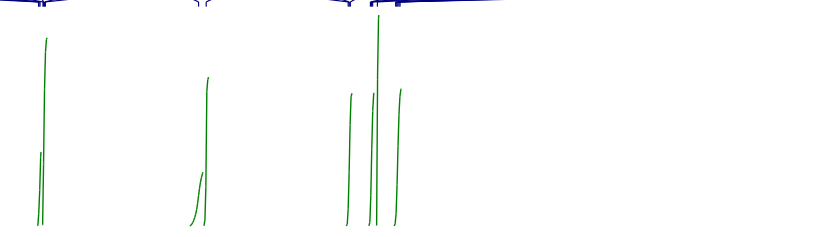<smiles>Cc1ccccc1CNc1c(Cl)c(Cl)nc(C(=O)C2=C(O)CCCC2=O)c1Cl</smiles>

Figure 22 The $\left.{ }^{13} \mathrm{C} \mathrm{NMR} \mathrm{(100M} \mathrm{CDCl}_{3}\right)$ of compound 20

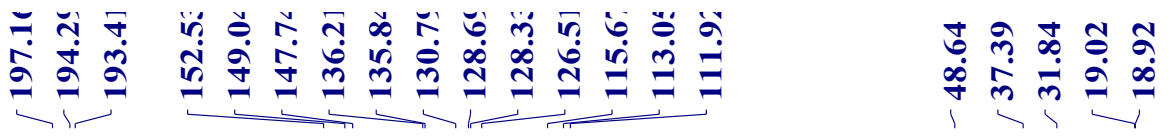<smiles>Cc1ccccc1CNc1c(Cl)c(Cl)nc(C(=O)C2=C(O)CCCC2=O)c1Cl</smiles> 
Figure 23 The ${ }^{1} \mathrm{H}$ NMR (400M $\mathrm{CDCl}_{3}$ ) of compound 21

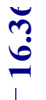<smiles>C=C</smiles>

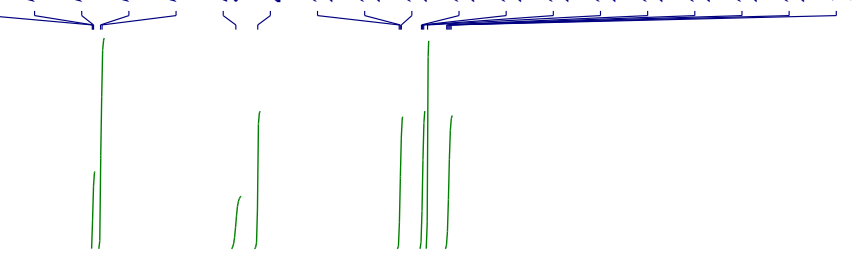<smiles>Cc1cccc(CNc2c(Cl)c(Cl)nc(C(=O)C3=C(O)CCCC3=O)c2Cl)c1</smiles>

Figure 24 The $\left.{ }^{13} \mathrm{C} \mathrm{NMR} \mathrm{(100M} \mathrm{CDCl}_{3}\right)$ of compound 21

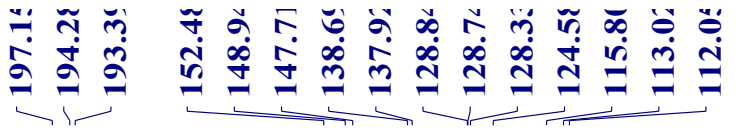<smiles>Cc1cccc(CNc2c(Cl)c(Cl)nc(C(=O)C3=C(O)CCCC3=O)c2Cl)c1</smiles> 
160

Figure 25 The ${ }^{1} \mathrm{H}$ NMR (400M CDCl $\mathrm{M}_{3}$ ) of compound 22

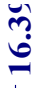

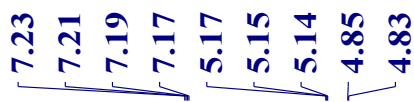

$\mid$<smiles>Cc1ccc(CNc2c(Cl)c(Cl)nc(C(=O)C3=C(O)CCCC3=O)c2Cl)cc1</smiles>

161

Figure 26 The ${ }^{13} \mathrm{C}$ NMR $\left(100 \mathrm{M} \mathrm{CDCl}_{3}\right)$ of compound 22
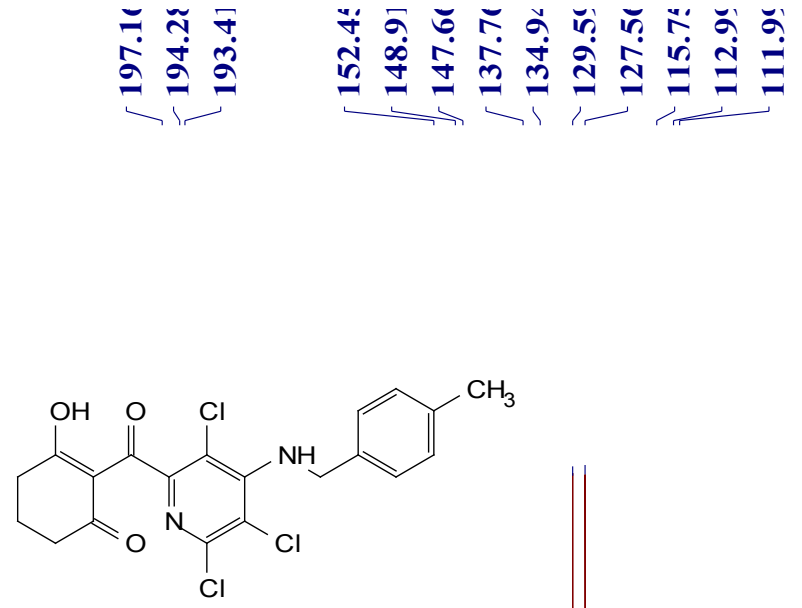

$\begin{array}{lllllllllllllllllllllllllllllllll}240 & 230 & 220 & 210 & 200 & 190 & 180 & 170 & 160 & 150 & 140 & 130 & 120 & 110 & 100 & 90 & 80 & 70 & 60 & 50 & 40 & 30 & 20 & 10 & 0 & -1\end{array}$ 
Figure 27 The ${ }^{1} \mathrm{H}$ NMR (400M $\mathrm{CDCl}_{3}$ ) of compound 23

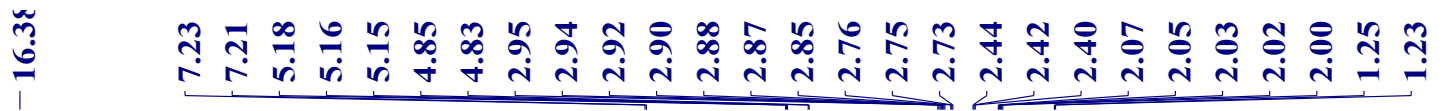

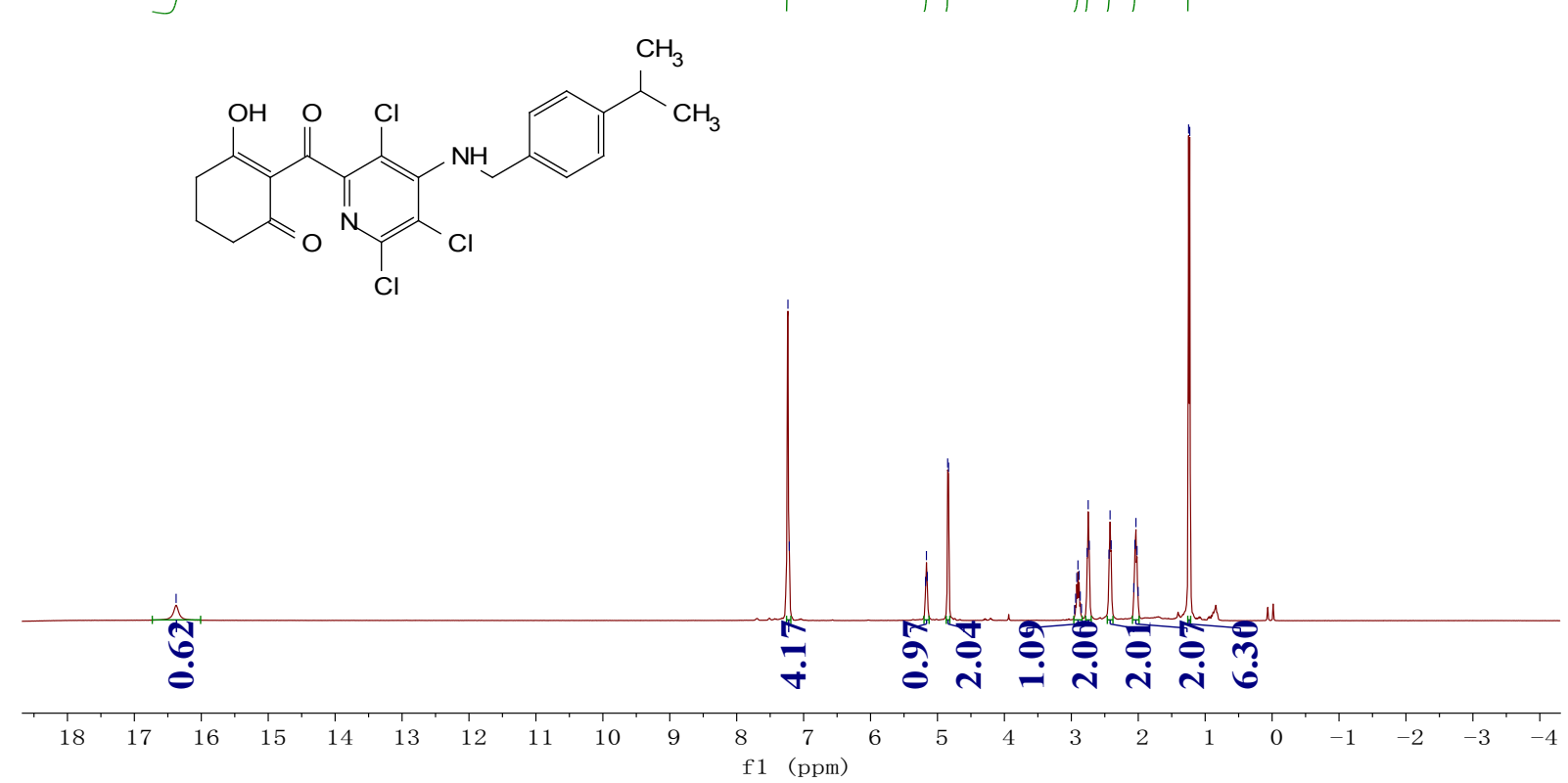<smiles>c1ccccc1</smiles>

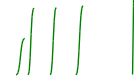

Figure 28 The ${ }^{13} \mathrm{C}$ NMR $\left(100 \mathrm{M} \mathrm{CDCl}_{3}\right)$ of compound 23

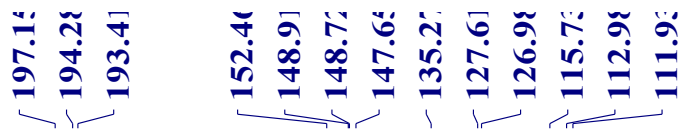<smiles>CC(C)c1ccc(CNc2c(Cl)c(Cl)nc(C(=O)C3=C(O)CCCC3=O)c2Cl)cc1</smiles> 
Figure 29 The ${ }^{1} \mathrm{H} \mathrm{NMR}\left(400 \mathrm{M} \mathrm{CDCl}_{3}\right.$ ) of compound 24

กัด ๓ิ<smiles>CC(C)(C)c1ccc(CNc2c(Cl)c(Cl)nc(C(=O)C3=C(O)CCCC3=O)c2Cl)cc1</smiles>

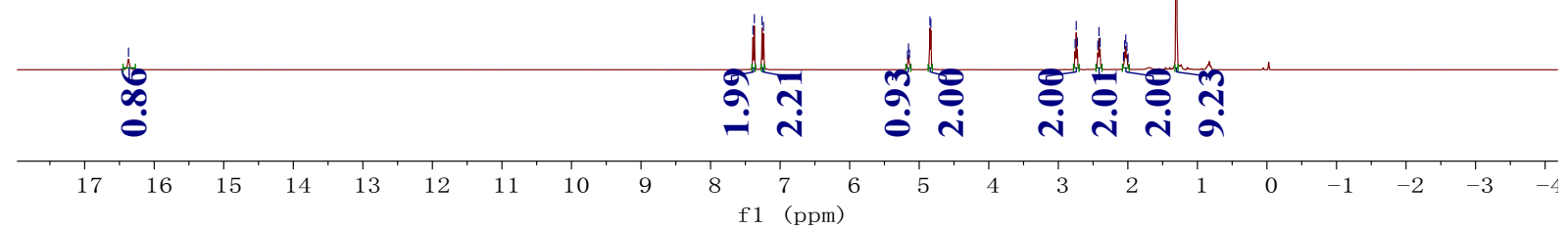

Figure 30 The ${ }^{13} \mathrm{C} \mathrm{NMR} \mathrm{(100M} \mathrm{CDCl}{ }_{3}$ ) of compound 24

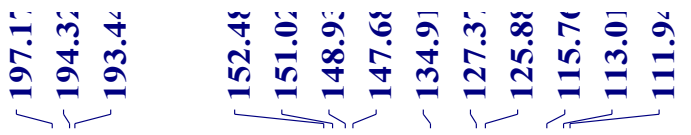<smiles>CC(C)(C)c1ccc(CNc2c(Cl)c(Cl)nc(C(=O)C3=C(O)CCCC3=O)c2Cl)cc1</smiles> 
Figure 31 The ${ }^{1} \mathrm{H}$ NMR (400M $\mathrm{CDCl}_{3}$ ) of compound 25
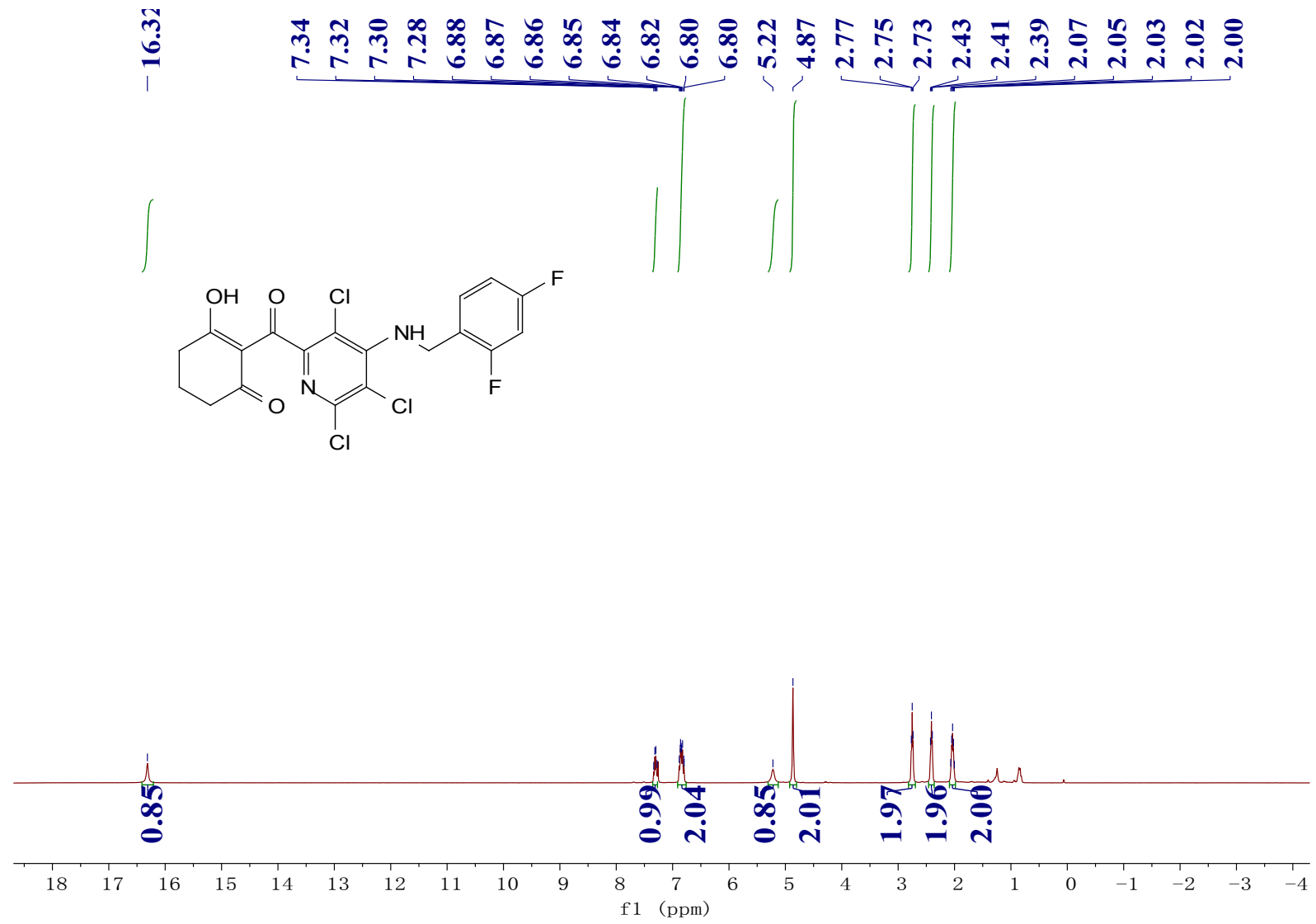

Figure 32 The $\left.{ }^{13} \mathrm{C} \mathrm{NMR} \mathrm{(100M} \mathrm{CDCl} 3\right)$ of compound 25

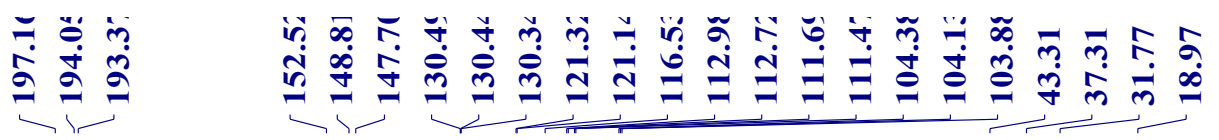<smiles>O=C1CCCC(O)=C1C(=O)c1nc(Cl)c(Cl)c(NCc2ccc(F)cc2F)c1Cl</smiles>

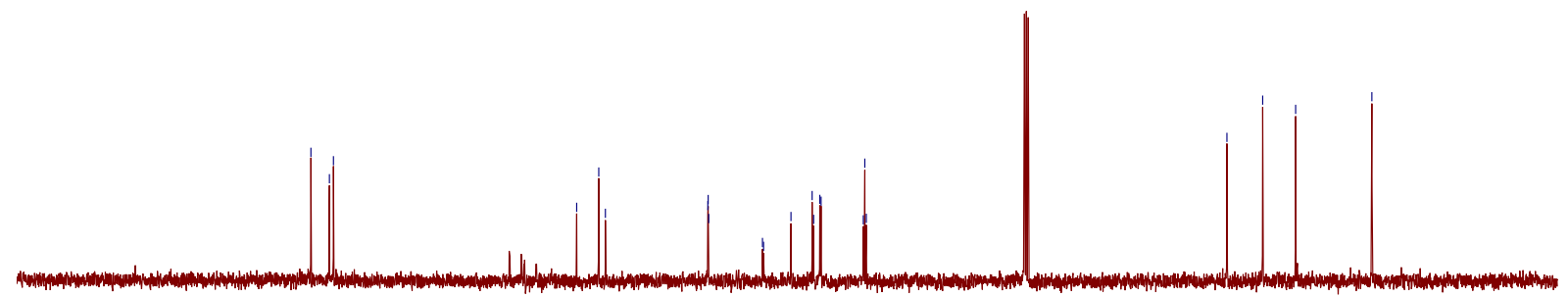


176

Figure 33 The ${ }^{1} \mathrm{H}$ NMR (400M $\mathrm{CDCl}_{3}$ ) of compound 26

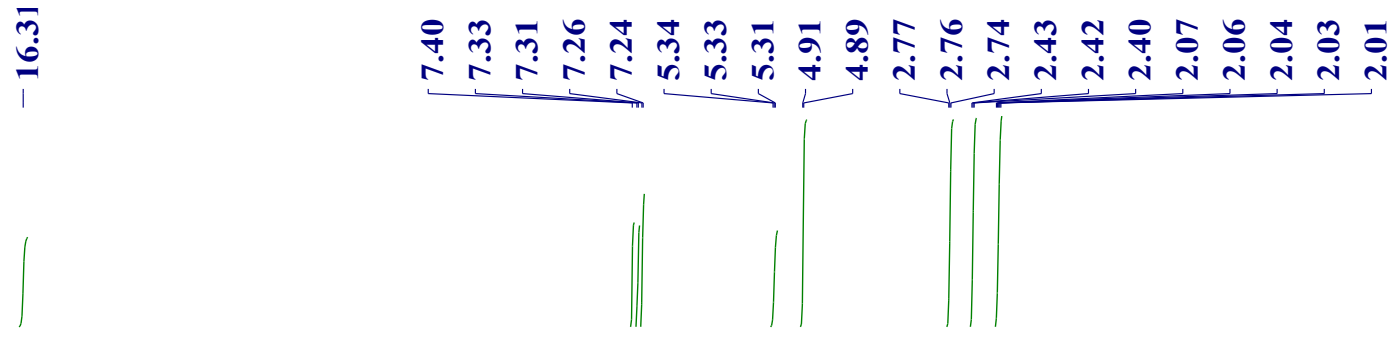<smiles>O=C1CCCC(O)=C1C(=O)c1nc(Cl)c(Cl)c(NCc2ccc(Cl)cc2Cl)c1Cl</smiles>

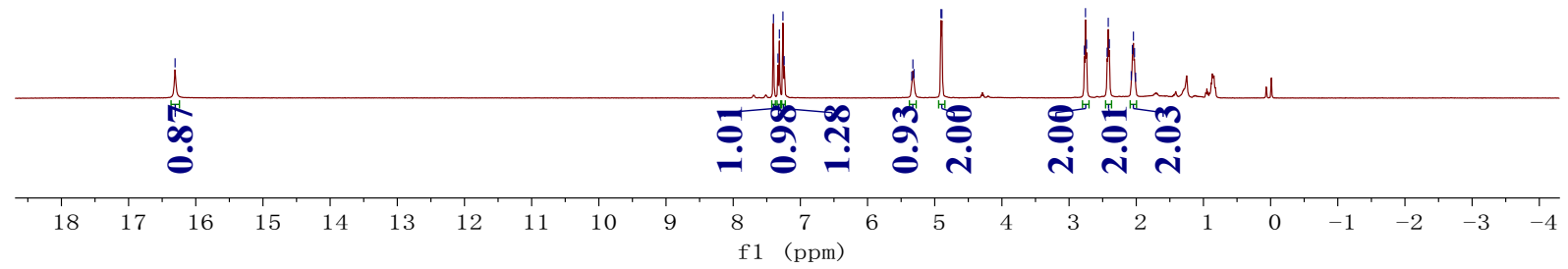

Figure 34 The ${ }^{13} \mathrm{C}$ NMR $\left(100 \mathrm{M} \mathrm{CDCl}_{3}\right)$ of compound 26

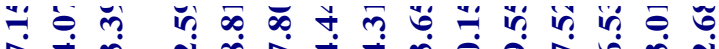

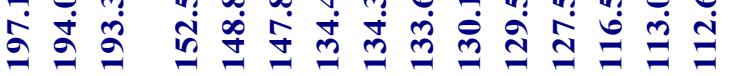

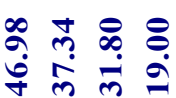<smiles>O=C1CCCC(O)=C1C(=O)c1nc(Cl)c(Cl)c(NCc2ccc(Cl)cc2Cl)c1Cl</smiles>

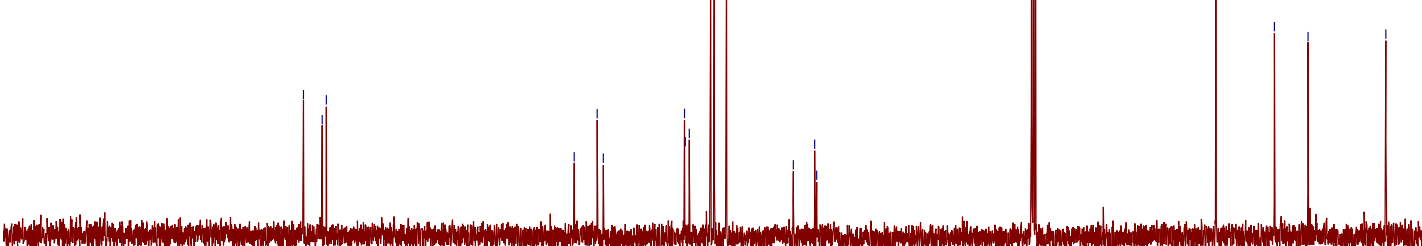

$\begin{array}{llllllllllllllllllllllllll}240 & 230 & 220 & 210 & 200 & 190 & 180 & 170 & 160 & 150 & 140 & 130 & 120 & 110 & 100 & 90 & 80 & 70 & 60 & 50 & 40 & 30 & 20 & 10 & 0 & -1\end{array}$ 
Figure 35 The ${ }^{1} \mathrm{H}$ NMR (400M $\mathrm{CDCl}_{3}$ ) of compound 27

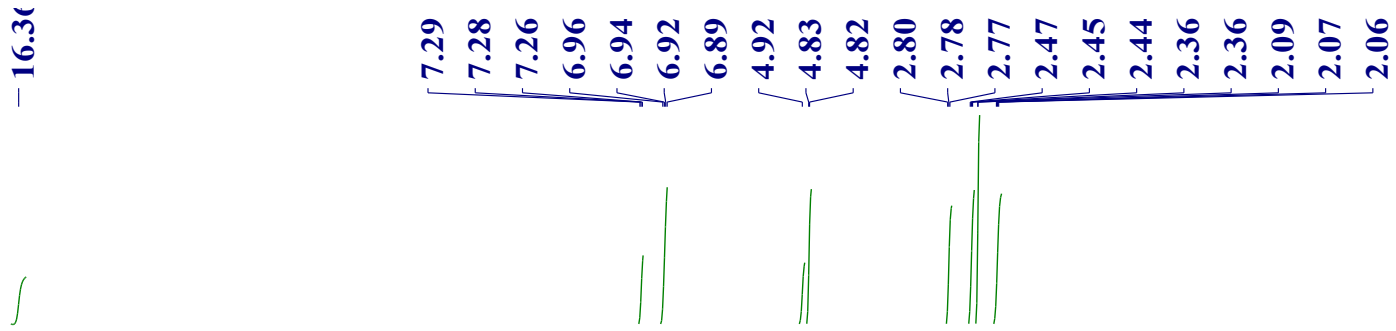<smiles>Cc1cc(F)ccc1CNc1c(Cl)c(Cl)nc(C(=O)C2=C(O)CCCC2=O)c1Cl</smiles>

Figure 36 The ${ }^{13} \mathrm{C} \mathrm{NMR}\left(100 \mathrm{M} \mathrm{CDCl}_{3}\right)$ of compound 27

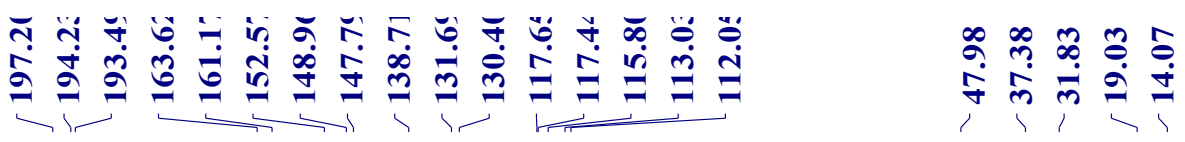<smiles>Cc1cc(F)ccc1CNc1c(Cl)c(Cl)nc(C(=O)C2=C(O)CCCC2=O)c1Cl</smiles> 
Figure 37 The ${ }^{1} \mathrm{H}$ NMR (400M $\mathrm{CDCl}_{3}$ ) of compound 28

กับ<smiles>Cc1ccc(F)cc1CNc1c(Cl)c(Cl)nc(C(=O)C2=C(O)CCCC2=O)c1Cl</smiles>

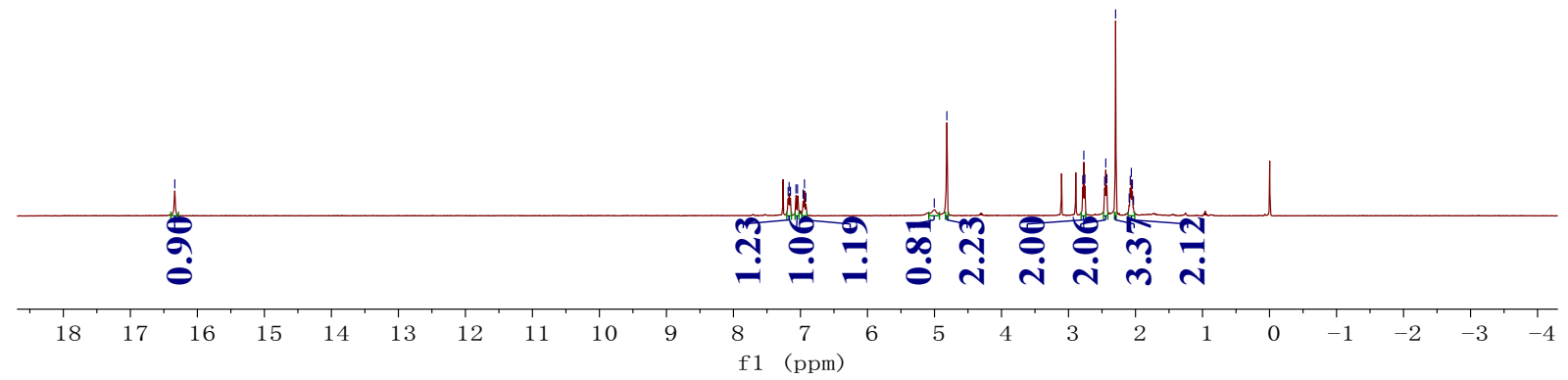

Figure 38 The $\left.{ }^{13} \mathrm{C} \mathrm{NMR} \mathrm{(100M} \mathrm{CDCl}_{3}\right)$ of compound 28

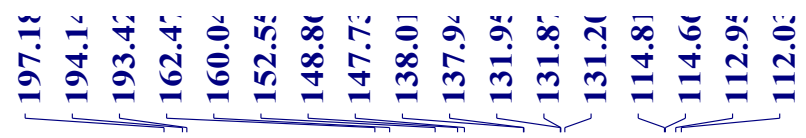<smiles>Cc1ccc(F)cc1CNc1c(Cl)c(Cl)nc(C(=O)C2=C(O)CCCC2=O)c1Cl</smiles> 
Figure 39 The ${ }^{1} \mathrm{H}$ NMR (400M $\mathrm{CDCl}_{3}$ ) of compound 29<smiles>Cc1ccc(CNc2c(Cl)c(Cl)nc(C(=O)C3=C(O)CCCC3=O)c2Cl)c(C)c1</smiles>

Figure 40 The ${ }^{13} \mathrm{C}$ NMR $\left(100 \mathrm{M} \mathrm{CDCl}_{3}\right)$ of compound 29

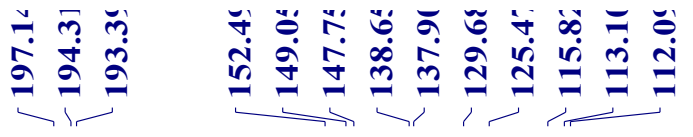<smiles>Cc1ccc(CNc2c(Cl)c(Cl)nc(C(=O)C3=C(O)CCCC3=O)c2Cl)c(C)c1</smiles>
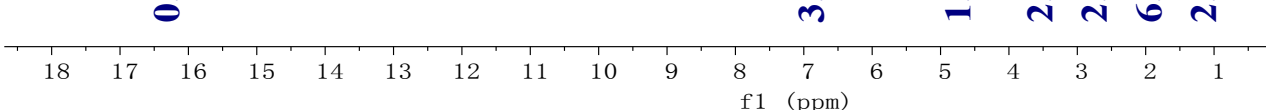
Figure 41 The ${ }^{1} \mathrm{H}$ NMR (400M $\mathrm{CDCl}_{3}$ ) of compound 30

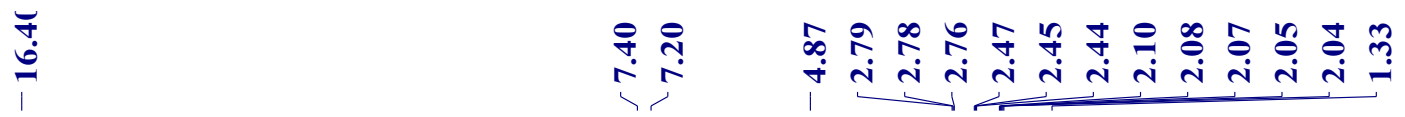<smiles>CC(C)(C)c1cc(CNc2c(Cl)c(Cl)nc(C(=O)C3=C(O)CCCC3=O)c2Cl)cc(C(C)(C)C)c1</smiles>

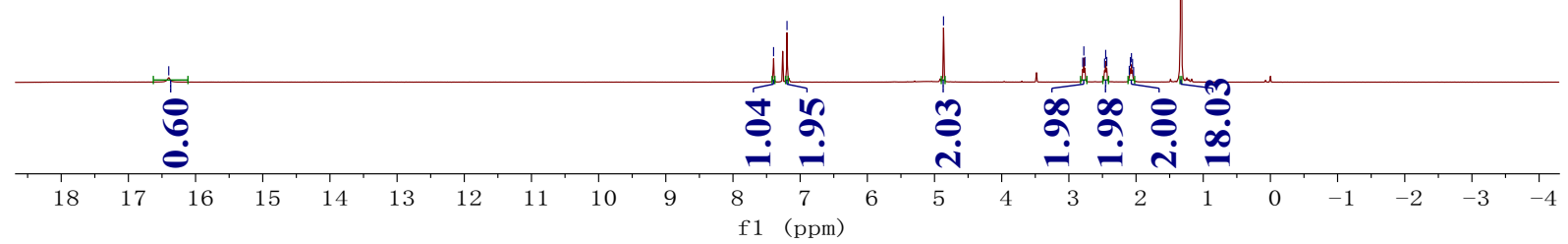

Figure 42 The ${ }^{13} \mathrm{C}$ NMR $\left(100 \mathrm{M} \mathrm{CDCl}_{3}\right)$ of compound 30

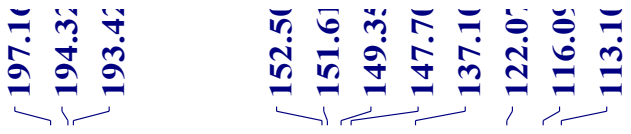<smiles>CC(C)(C)c1cc(CNc2c(Cl)c(Cl)nc(C(=O)C3=C(O)CCCC3=O)c2Cl)cc(C(C)(C)C)c1</smiles> 
Figure 43 The ${ }^{1} \mathrm{H}$ NMR (400M $\mathrm{CDCl}_{3}$ ) of compound 31

ֻேं<smiles>CN(Cc1ccc(F)cc1)c1c(Cl)c(Cl)nc(C(=O)C2=C(O)CCCC2=O)c1Cl</smiles>

Figure 44 The ${ }^{13} \mathrm{C}$ NMR (100M $\left.\mathrm{CDCl}_{3}\right)$ of compound 31

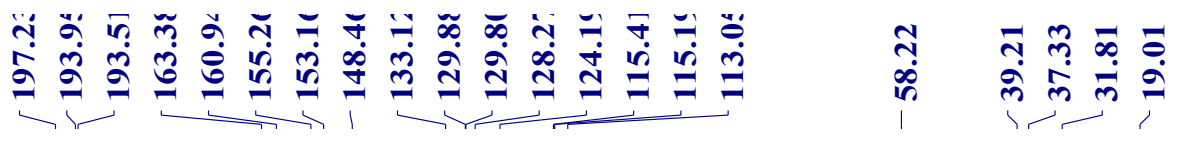<smiles>CN(Cc1ccc(F)cc1)c1c(Cl)c(Cl)nc(C(=O)C2=C(O)CCCC2=O)c1Cl</smiles> 
Figure 45 The ${ }^{1} \mathrm{H}$ NMR (400M $\mathrm{CDCl}_{3}$ ) of compound 32

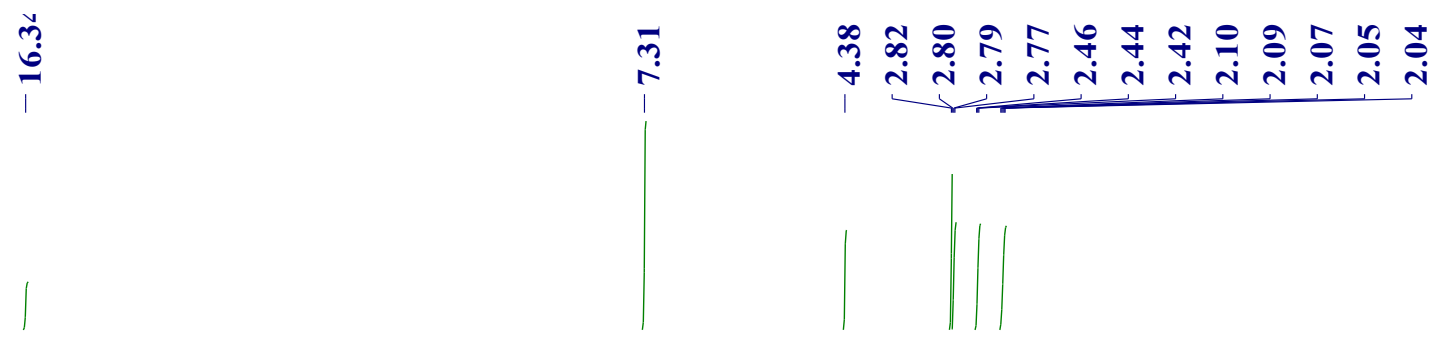<smiles>CN(Cc1ccc(Cl)cc1)c1c(Cl)c(Cl)nc(C(=O)C2=C(O)CCCC2=O)c1Cl</smiles>

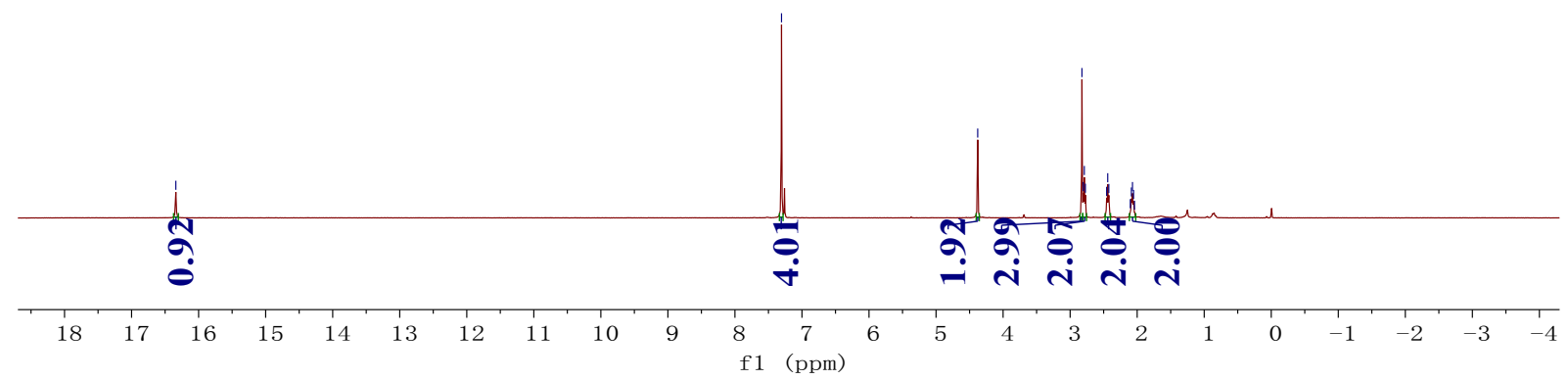

Figure 46 The ${ }^{13} \mathrm{C}$ NMR $\left(100 \mathrm{M} \mathrm{CDCl}_{3}\right)$ of compound 32

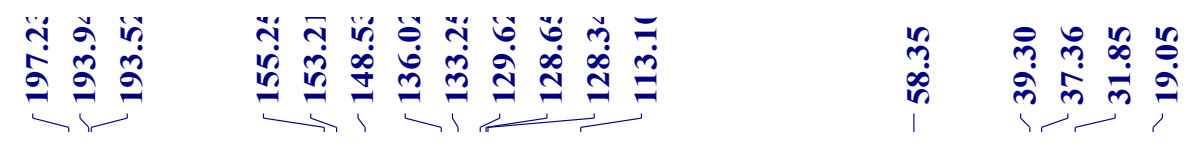<smiles>CN(Cc1ccc(Cl)cc1)c1c(Cl)c(Cl)nc(C(=O)C2=C(O)CCCC2=O)c1Cl</smiles> 
Figure 47 The ${ }^{1} \mathrm{H} \mathrm{NMR}\left(400 \mathrm{M} \mathrm{CDCl}_{3}\right.$ ) of compound 33

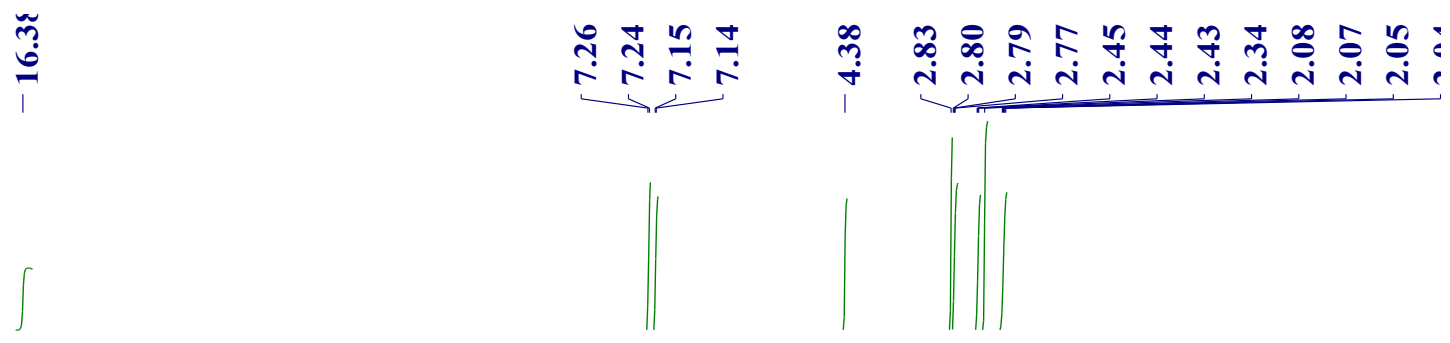<smiles>Cc1ccc(CN(C)c2c(Cl)c(Cl)nc(C(=O)C3=C(O)CCCC3=O)c2Cl)cc1</smiles>

Figure 48 The ${ }^{13} \mathrm{C}$ NMR $\left(100 \mathrm{M} \mathrm{CDCl}_{3}\right)$ of compound 33

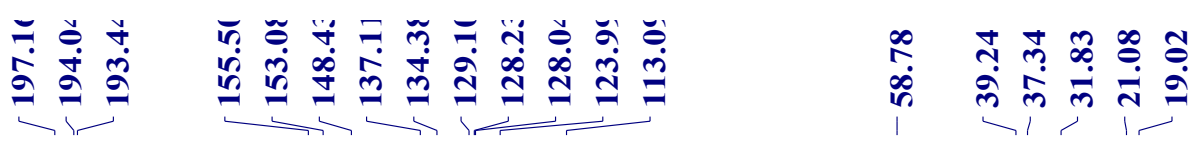<smiles>Cc1ccc(CNc2c(Cl)c(Cl)nc(C(=O)C3=C(O)CCCC3=O)c2Cl)cc1</smiles> 
Figure 49 The ${ }^{1} \mathrm{H}$ NMR (400M $\mathrm{CDCl}_{3}$ ) of compound 34

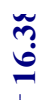
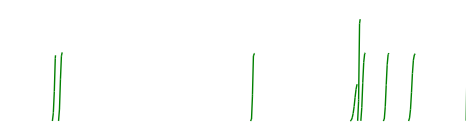<smiles>CC(C)c1ccc(CN(C)c2c(Cl)c(Cl)nc(C(=O)C3=C(O)CCCC3=O)c2Cl)cc1</smiles>

Figure 50 The ${ }^{13} \mathrm{C}$ NMR (100M $\left.\mathrm{CDCl}_{3}\right)$ of compound 34

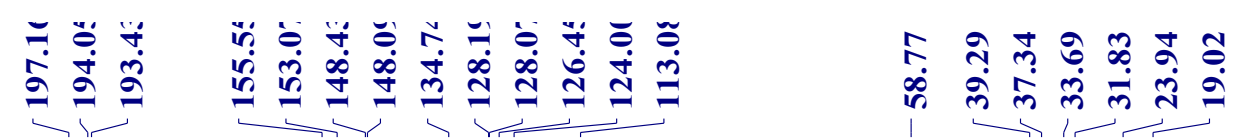<smiles>CC(C)c1ccc(CN(C)c2c(Cl)c(Cl)nc(C(=O)C3=C(O)CCCC3=O)c2Cl)cc1</smiles> 
Figure 51 The ${ }^{1} \mathrm{H}$ NMR (400M $\mathrm{CDCl}_{3}$ ) of compound 35

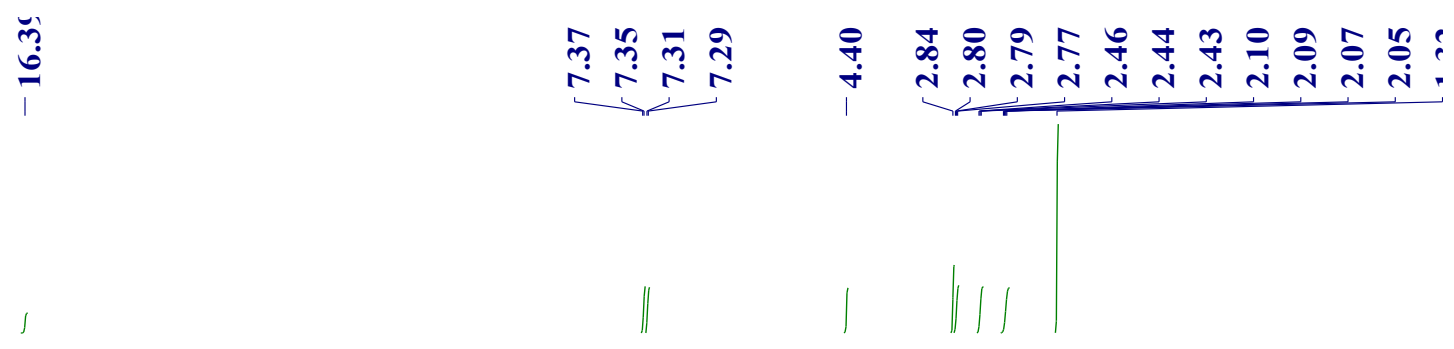<smiles>CN(Cc1ccc(C(C)(C)C)cc1)c1c(Cl)c(Cl)nc(C(=O)C2=C(O)CCCC2=O)c1Cl</smiles>

Figure 52 The $\left.{ }^{13} \mathrm{C} \mathrm{NMR} \mathrm{(100M} \mathrm{CDCl}_{3}\right)$ of compound 35

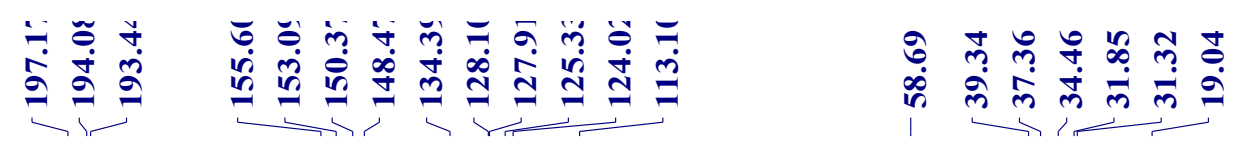<smiles>CN(Cc1ccc(C(C)(C)C)cc1)c1c(Cl)c(Cl)nc(C(=O)C2=C(O)CCCC2=O)c1Cl</smiles>

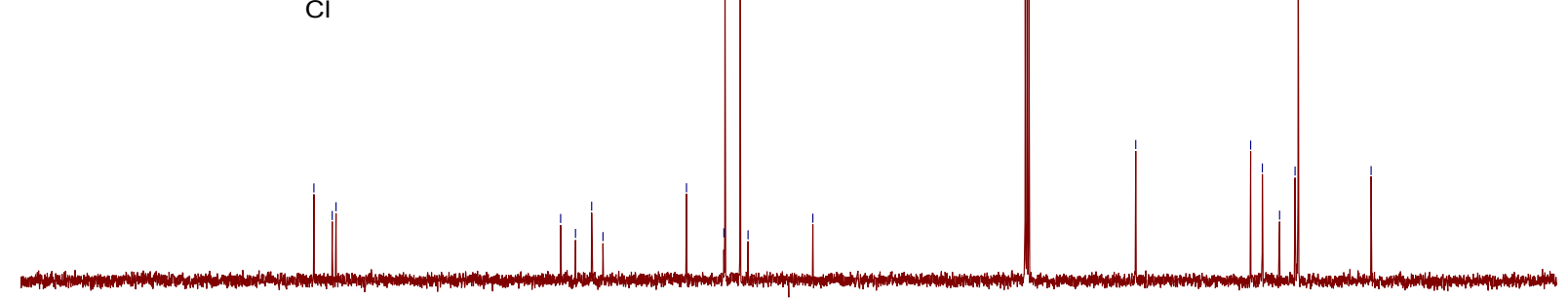


Figure 53 The ${ }^{1} \mathrm{H}$ NMR (400M $\mathrm{CDCl}_{3}$ ) of compound 36

กั่

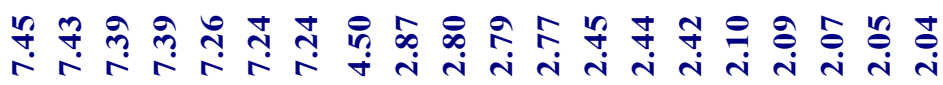<smiles>C=CC</smiles>
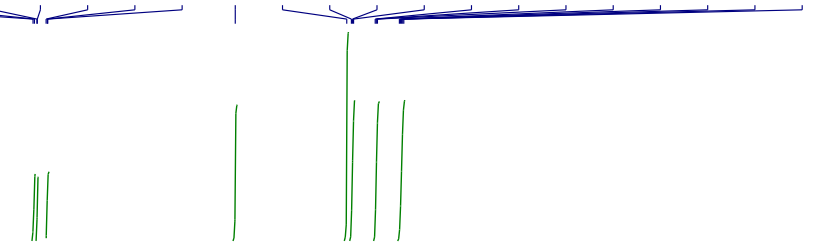<smiles>CN(Cc1ccc(Cl)cc1Cl)c1c(Cl)c(Cl)nc(C(=O)C2=C(O)CCCC2=O)c1Cl</smiles>

Figure 54 The ${ }^{13} \mathrm{C}$ NMR (100M $\left.\mathrm{CDCl}_{3}\right)$ of compound 36

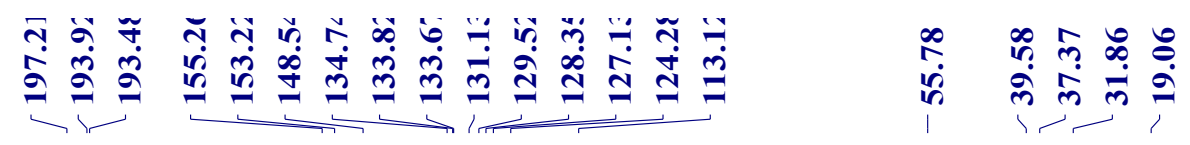<smiles>CN(Cc1ccc(Cl)cc1Cl)c1c(Cl)c(Cl)nc(C(=O)C(=O)C2=C(O)CCCC2=O)c1Cl</smiles> 